Research Square

\title{
Drought Effects on Growth, Water Content, and Organic Osmoprotectants in Promising Almond Genotypes with Different Drought Tolerance
}






\section{Abstract}

Background Almonds (Prunus amygdalus Batsch, syn. P. dulcis (Mill.) DA Webb) is a valuable nut crops species that is widely is cultivated in arid and semi-arid regions of Iran, due to drought tolerance and dehydration under drought stress. Almonds show physiological adaptations for survival in drought stress conditions, but the degree Drought adaptation varies between cultivars. However, to date, its morphological and physiological responses to drought, and the underlying mechanisms are not well understood. This study was aimed to investigate the morphological and physiological changes of almond genotypes under drought stress. almond genotypes were planted in pots and subjected to four levels of soil water treatments: above $80 \%$ (control), $60 \%$ (light stress), and $40 \%$ (severe stress) of field capacity. Results Within the total stress period (0-30 days), almond genotypes grew rapidly in the light stress, whereas severe stress had a negative impact on growth. So that, in this study, 10 selected almond genotypes using some morphological traits such as: plant height, trunk diameter at the top of the graft, new branch growth length, leaf yellowness and some physiological indicators under drought stress conditions such as Chlorophyll index was evaluated based on SPAD criterion, relative leaf water content, measurement of chlorophyll fluorescence and Organic Osmoprotectants to identify drought-resistant and sensitive genotypes under drought stress conditions. Among the selected genotypes studied, genotype A-7-100 was the most resistant and genotype A-124-1 was the most sensitive to drought stress. Conclusions Our results show that almond genotypes adapt to drought mainly by avoidance mechanisms, and its morphological and physiological characteristics are inhibited under severe stress, However, the degree of drought adaptation varies between different cultivars. These findings might help limited water resources to be fully used for increased the percentage of kernel and finally increased the growth and yield of plants under water stress.

\section{Background}

Almonds (Prunus amygdalus Batsch, syn. P. dulcis (Mill.) DA Webb) belong to the Rosaceae family, sub-family Prunoidea, genus Prunus and sub-genus Amygdalus native to the Iranian plateau and Iran is one of the important producers in the world (Karimi et al. 2013). So that, according to the FAO statistics (2019), out of the total world production of 3497148 tons the United States, Spain, Iran, Turkey, Australia, Morocco, Syria, Tunisia, Italy and Algeria have the highest Production with 1936840, 340420, 177015,150000, 146410,102185,80258, 80000,77300 and 72412 tons respectively. On the other hand, although almonds are a drought-resistant species, but with climate change, drought stress is increasingly becoming one of the main limiting factor for horticultural plant growth. Plants can change their morphological, physiological and metabolism-related responses at both organ and cellular levels to reduce the drought severity (Haider, et al. 2018).

With climate change, drought stress has become more common and its impact on existing ecosystems is more important to the scientific community. Evidence suggests that stress affects physical stress in the ecosystem (Khoyerdi et al. 2016). The agricultural sector is an integral part of the ecosystem and is affected by this pressure. Therefore, drought stress is one of the main problems in agricultural production and is an important factor in reducing crop yields and is critical for growing plants that are resistant to stress and can maintain yield stability in drought conditions (Rouhi et al. 2007). According to the FAO (2010), low rainfall and uneven distribution of rainfall during the growing season in arid and semi-arid regions of the world, including Iran, has led to the need for water and crops to meet the required water.

Today, due to widespread climate change and the lack of water resources required for the cultivation of agricultural crops, it is necessary to use cultivars resistant to environmental limiting factors such as drought stress for economic production (Egea et al. 2010). Plants in the face of environmental stresses in order to deal with the adverse effects of biological and abiotic stresses and in order to survive, various mechanisms such as drought avoidance, drought tolerance and drought escape Scape (Ryan, 2013). Also, the use of correct management methods in the production of agricultural crops, such as proper management of agricultural water use, selection of cultivars and rootstocks suitable for the climatic conditions of the cultivation area and also the use of improved cultivars to produce an almond crop with proper yield in this areas will be (Samandari et al. 2012; Berman and Dejong, 1996; Nezhadahmadi et al. 2013).

One of the most important issues related to the cultivation of plants in saline and dry soils is the more negative osmotic potential of soil solution which will lead to a decrease in water absorption, which in turn has adverse effects on the osmotic potential of leaves ( $\Psi$ s), content relative humidity (RWC), leaf water potential (w $\Psi)$ and leaf turgor potential $(\Psi p)$ (Munné-Bosch et al. 2003; Hernández et al. 2004).

Photosynthesis is one of the important physiological processes in plants that its intensity decreases sternly under conditions of moisture stress. Moisture stress has a negative effect on the structural proteins of chlorophyll, reducing the light-absorbing pigments in photosystem II. Therefore, photosystem II plays an important role in photosynthetic reactions to environmental factors in higher plants, and the chlorophyll fluorescence technique has been considered by many researchers in recent years in plant ecophysiological studies as a fast, accurate and nondestructive method (Yuan et al. 2005; Baker and Rosenqvist 2004; Parida and Das 2005)

Although almond trees have a high drought tolerance. However, as the available water decreases, its performance decreases. This plant in low water conditions can produce little yield that prevents the production of other plant species. Its optimal performance is achieved by adequate water supply, especially in high-yield potential genotypes (Torrecillas et al. 1989). Almond germplasm diversity has been observed to increase drought resistance (Socias Company and Gradziel 2017). Because the tolerance of different cultivars and species of almonds to drought stress is different, and on the other hand, for economic production, almond trees must be irrigated during the growing season (Samandari Gikloo and 
Elhami 2012; Romero et al., 2004. Karimi et al.., 2013). Physiological, morphological and biochemical reactions of different almond cultivars are different under drought stress conditions (Germanà 1997). For example, according to a report, Masbavara cultivar has higher osmotic adaptation and water potential, lower evapotranspiration rate, better photosynthesis rate, higher water use efficiency and lower root hydraulic resistance compared to Laurent cultivar, and Masbavara cultivar is better adapted to cultivation conditions. (Socias Company and Gradziel 2017). Rouhi et al. (2007) reported that drought stress caused the leaves of Scoparia species to fall, while lycoides species had larger leaves than Scoparia species under drought stress conditions and some of the leaves were healthy and able to Were photosynthetic (Rouhi et al. 2007). In fact, in order to carry out breeding programs and produce drought-resistant cultivars, knowledge of the physiological and morphological behavior of cultivars against drought stress is necessary. The study of almond trees' reaction to irrigation conditions showed that trunk diameter growth, tree canopy height and width and crop yield were closely related to different levels of irrigation and low levels of irrigation and water stress led to a decrease in kernel percentage and ultimately reduced yield (Torrecillas et al., 1989). The higher the morphological and physiological variability and flexibility of the plant, the higher its resistance to stress, ie it can return to its normal state sooner after stress and change less in the stress state (Vitagliano and Sebastiani 2002).

The use of drought tolerant and drought tolerant species is one of the strategies to deal with water shortage in the agricultural sector, which will be possible by selecting drought tolerant cultivars by examining their performance under drought stress conditions (Arji et al. 2000). Since plant performance is influenced by physiological and biochemical traits, these traits can be used as a tool to identify and select drought tolerant plants. For this purpose, the genotypes of a plant species in terms of physiological and biochemical traits and their relationship with drought tolerance are examined (Ge et al. 2014). Therefore, considering the spread of drought and the importance of drought-resistant genotypes, recognizing the performance of these genotypes and their resistance to drought conditions is a fundamental step in maintaining and developing these genotypes in the revitalization and development of almond orchards in semi-arid regions. On the other hand, vegetative and physiological responses under water stress can help us better understand these cultivars. Therefore, in this study, we tried to use different indicators to select stress-tolerant genotypes in order to identify more drought tolerant cultivars. Accordingly, the present study aimed to evaluate the drought tolerance of 10 new almond genotypes by examining the growth, water content and accumulation of organic preservatives in their leaves in response to different levels of irrigation.

\section{Materials And Methods}

The experiment was carried out in the Department of Horticultural Science at Tehran University. Plant materials were obtained from ten promising almond genotypes.'. Monitoring the growth, flowering, and yield of these for 7 years had indicated that they are promising genotypes for development of almond in drought regions. the drought tolerance of these plants was yet to be determined prior to extend their cultivation in semi-arid regions. Two-year-old plants /GN15 of these cultivars were transplanted into large pots, containing $12 \mathrm{~kg}$ of a mixture of soil, sand, and leaf mold (1:1:1). The soil used has 36.5 clay, 31. \% lum, 32.5 sand, $7 \mathrm{pH}, 1.2 \mathrm{EC}$ decisation per meter, $0.18 \%$, percent, nitrogen $0.17 \%$, organic matter $1.70 \%$, absorbable phosphorus, absorbable potassium, zinc, manganese, iron and copper 6.1,195,0.59, 12,5.1 and 0.95 $\mathrm{ml} / \mathrm{kg}$, respectively. The plants were established in a greenhouse with a day/night cycle of $30 / 22^{\circ} \mathrm{C}$ and $15 \%$ relative humidity for 60 days. Plants were pruned consistently throughout the establish-ment stage in order to obtain uniform shoots. Drought stress was imposed on the plants in the same environmental conditions as above, by withholding the irrigation for 30 days. Drought stress treatments were applied at three levels, 40\%, 60 and $100 \%$ of field capacity.

After establishment, the plants were gradually prepared for drought stress. The stress factor consisted of three levels that were determined based on soil water potential ( $\Psi$ soil); So that soil water potential $-0.33 \mathrm{MPa}$ as a control, equivalent to 0.8 and 1.6 MPa were considered as moderate and severe stress, respectively. To reach the desired stress levels after stopping irrigation, the volume of soil moisture of pots was read daily using Time Domain Reflectometry. Also, by sampling the soil from the additional pots provided, the potential of the soil matrix in the volume moisture read with the pressure plate 4 was determined and finally the relationship between the volume moisture and the soil water potential was determined and its diagram was determined (Figure 1) (Jimenez et al. 2013). Thus, the amount of soil water potential was determined through a number read by Time Domain Reflectometry. After reaching the desired potential, the weight of each pot was determined at this point. By weighing the pots every two days, the equivalent of the reduced weight of water was given to the pot (Karimi et al. 2013). The plants were stressed for four weeks. Volumetric balance method or drainage lysimeter method was applied. Equation

$\Delta S=I-O$

\section{l: Feed water to the pot,}

\section{$O$ : Water drained from the bottom of the pot and}

\section{$\Delta S$. Compensate for the moisture out of the soil between two watering due to evapotranspiration.}

It should be noted that irrigation levels were extracted based on the studied scientific sources (Karimi et al. 2013) and the soil moisture characteristic curve used ( $\square$ Curve q-P).

Determine the morphological traits

All morphological traits related to vegetative growth were measured by digital caliper. 
Determine the leaf water (RWC)

To measure the relative content of leaf water (RWC), fully developed leaves were sampled. After harvesting the leaf samples from the desired treatments, they were weighed immediately.

Then the plant samples were immersed in $15 \mathrm{ml}$ of distilled water $\left(25^{\circ} \mathrm{C}\right)$ and after 16 hours they were removed from the distilled water and their fresh weight was recorded again. The weighed samples were dried in paper bags in an oven (70 ${ }^{\circ} \mathrm{C}$ ) for 48 hours. Percentage of relative water content was calculated using the following equation.

Relative leaf water content $(\%)=[$ (fresh weight - dry weight) / (saturated weight - dry weight) $] \times 100$

Determine the chlorophyll index

The amount of greenery (chlorophyll index) was recorded by the device (Soil plant analysis development) (Model: Minolta, Japan) SPAD-502 without destruction of plant tissue and from three midpoints of leaves (Gholizadeh 2009).

Determine the chlorophyll fluorescence

Chlorophyll fluorescence changes were measured using a chlorophyll fluorescence measuring device (Opti-Sciences, Model: OS-30p, USA). Using a fluorescence measuring device, after exposing the leaf to active light (800 micromoles per square meter per second), the fluorescence energy of chlorophyll increases and reaches the FO (Fluorescence Optimum) level. At the FO level, the power consumption of the excited energy is at its optimum value. When the light intensity is sufficient, the fluorescence then increases from the FO value to its maximum value (Fluorescence maximum) Fm. This increase indicates a gradual increase in fluorescence performance and a decrease in the rate of photochemical reactions. One of the important parameters of chlorophyll fluorescence is $\mathrm{F}_{\mathrm{v}} / \mathrm{F}_{\mathrm{m}}$, which is inversely related to stress. To evaluate different treatments under stress, the digital device automatically shows its value in measurements of leaf samples in different treatments (Baker and Rosenqvist, 2004).

Determine the chlorophylls and total carotenoids

The Chl $a$, Chl $b$ and total carotenoids were determined by the method of Yang et al. (1998). Extract preparation procedure was identical to the previously described method. The acetone-water mixture (4:1) was used as a solvent. The absorbance maxima were read at $663.6 \mathrm{~nm}$ for $\mathrm{Chl} a, 646.6 \mathrm{~nm}$ for Chl $b$ and $470.0 \mathrm{~nm}$ for carotenoids. Contents of Chl $a$, Chl $b$ and total carotenoids were calculated from the following equations:

Chlorophyll a: $\mathrm{Ca}=12.25$ A663.2 - 2.25 A646.6 ( $\mu$ g per ml solution)

Chlorophyll b: $\mathrm{C} b=20.31$ A646.6 - 4.91 A663.6 ( $\mu$ g per ml solution)

Total carotenoids: $\mathrm{Cx}+\mathrm{C}=(1000 \mathrm{~A} 470-2.27 \mathrm{Ca}-81.04 \mathrm{Cb}) / 227$ ( $\mu \mathrm{g}$ per ml solution)

Determine the proline

Proline levels were also measured separately. To measure proline, the leaves of samples treated with polyethylene glycol with different negative and control loads were used. The separated leaves were placed in foil and transferred to the laboratory in a nitrogen tank. Samples were stored in the laboratory at $-80^{\circ} \mathrm{C}$ until use. Proline was extracted from a sample of $0.5 \mathrm{~g}$ fresh leaf material samples in 3\% (w.v) aqueous sulphosalycylic acid and estimated using the ninhydrin reagent according to the method of (Bates et al. 1973). The absorbance of fraction with toluene aspired from liquid phase was read at a wave length of $520 \mathrm{~nm}$. Proline concentration was determined using a calibration curve and expressed as $\mu$ mol proline g-1 FW:

$$
\mu \text { moles } \frac{\text { proline }}{\mathrm{g}} \text { of fresh weight material }=\frac{\left[\frac{\mu g \frac{\text { proline }}{m l} \times \text { ml Toluene }}{115.5 \mu \frac{g}{\mu m o l e}}\right]}{\left(\mathrm{g} \frac{\text { sample }}{5}\right)}
$$

\section{Determine the activity of antioxidant enzymes}

First, $0.34 \mathrm{~g} \mathrm{KH2PO4,} 0.7 \mathrm{~g}$ PVPP and $0.3 \mathrm{~g}$ Na-EDTA were dissolved in $30 \mathrm{ml}$ distilled water and then the volume was dissolved in $50 \mathrm{ml}$ (phosphate buffer $\mathrm{pH}=6.8$ ). Then 0.44 grams of K2HPO4, $0.7 \mathrm{~g}$ of PVPP and Na-EDTA 0.3 in $30 \mathrm{~mL}$ distilled water were dissolved and the volume was diluted to $50 \mathrm{~mL}$ ( $\mathrm{pH}=7.2$ with phosphorus). Finally, $39 \%$ of the first buffer was combined with $61 \%$ of the second buffer (phosphate buffer $\mathrm{pH}=7$ ). In order to prepare an oxidizing water buffer (H2O2) of $225 \mathrm{mM}, 450 \mu \mathrm{l}$ of $\mathrm{H} 2 \mathrm{O} 2$ was mixed with $20 \mathrm{ml}$ phosphate buffer. A $45 \mu \mathrm{M}$ guaiacol buffer was also provided with $112 \mu \mathrm{l}$ guaiacol with $20 \mathrm{ml}$ phosphate buffer. The extract extraction step was performed using Sun et al. (2015) method. These extracts were used to measure the activity of enzymes (APX) and (POD). POD activity was estimated by changing absorbance at $470 \mathrm{~nm}$ (Sun et al. 2015)

The data were analyzed using SAS software (version 9.1 2002-2003, SAS Institute, Cary, NC, USA), The comparison of the meanings was done by the least significant difference test $(\mathrm{P}<0.05)$ with MSTAT-C software and the graphs were drawn also with Minitab software (version 17.3).

\section{Results And Discussion}

\section{Morphological traits}

The results of comparing the mean of the data are reported in Table 1. According to this report, the effect of drought stress on morphological characteristics of selected almond genotypes has been different. Under stress conditions, the highest height equal to $150.17 \mathrm{~cm}$ was recorded for genotype A-7-100 and the lowest height related to AH1-99 equal to 78.34 cm. However, in the stress-free state, this amount was for genotypes A-7-100 and AH1-99, 544/174 and 94 cm, respectively. These results indicate the negative effect of drought stress on the growth rate and height of selected genotypes. Stocker (1960) reported that drought stress reduces stem length and creates short stature in plants. Sivritepe et al. (2008) reported that the activity of indole acetic acid oxidase (IAAO) in growing plant tissues is very low, but the activity of this enzyme increases under drought stress and causes the analysis of auxin in plants. According to the results of comparison of the mean (Table 1), drought treatment had a significant effect on the size of trunk diameter above the graft site in selected almond genotypes. Genotypes 
A-7-100, A-5-6 and A-100-17 showed the highest diameter size compared to other genotypes. However, no significant difference was observed between these three genotypes (A-7-100), A-5-6 and (A-100-17. According to a report (Rigling et al., 2003), water deficiency can be negative effect on cell growth, prevents the formation and growth of wood vessels and reduces the diameter of the trunk. Regarding yellowing and leaf fall among the selected almond genotypes, the mean comparison results showed that AH1-99 and A-124-1 genotypes with an average of 59.45 and $56.67 \%$ of yellowing and leaf fall, respectively, had the highest rate in Among other genotypes (Table 1). McMichael et al. (1973) reported that the cause of reduced leaf / yellowing and leaf fall in response to drought stress was associated with increased ethylene production. Plants also reduce the intensity of transpiration through a mechanism by reducing the number of their leaves during the stress period, which is also evident in this study (Zokaee-Khosroshahi et al. 2014). Regarding the longitudinal growth rate of new shoots according to the results of the comparison, the genotypes A-7-100, A-100-13 and A-100-8 with 7.03, 6.78 and 6.87, respectively $6 \mathrm{~cm}$ had the highest longitudinal growth under drought stress, which indicates that these genotypes had better resistance and adaptation to drought stress than other genotypes. Nikoumanesh et al. (2011) examined the morphological and molecular diversity of 55 Iranian almond genotypes for almond breeding programs and selection of suitable rootstocks. There is a positive, so that the more trees grew, the longer the branches grew. Similar results were reported by ZokaeeKhosroshahi et al. (2014) that in this study, the longitudinal growth of branches in different almond genotypes were different in response to drought stress and it seems that this feature can be Used as a marker of drought stress in young almond seedlings.

Table 1: Comparison of mean morphological traits of selected almond genotypes in response to drought stress

\begin{tabular}{|c|c|c|c|c|c|c|c|c|c|c|c|c|}
\hline \multirow[t]{2}{*}{ Genotype } & \multicolumn{3}{|c|}{ Yellowing and leaf fall (\%) } & \multicolumn{3}{|c|}{$\begin{array}{c}\text { Diameter growth of the trunk above } \\
\text { the graft site }(\mathrm{mm})\end{array}$} & \multicolumn{3}{|c|}{$\begin{array}{l}\text { Longitudinal growth of new branches } \\
\qquad(\mathrm{Cm})\end{array}$} & \multicolumn{3}{|c|}{ Plant height $(\mathrm{Cm})$} \\
\hline & $\begin{array}{c}\text { Sever } \\
\text { stress }(40 \%)\end{array}$ & $\begin{array}{c}\text { Medium } \\
\text { stress }(60 \%)\end{array}$ & $\begin{array}{l}\text { Control } \\
(80 \%)\end{array}$ & $\begin{array}{c}\text { Sever } \\
\text { stress }(40 \%)\end{array}$ & $\begin{array}{c}\text { Medium } \\
\text { stress (60\%) }\end{array}$ & $\begin{array}{c}\text { Control } \\
(80 \%)\end{array}$ & $\begin{array}{c}\text { Medium } \\
\text { stress }(40 \%)\end{array}$ & $\begin{array}{c}\text { Medium } \\
\text { stress }(60 \%)\end{array}$ & $\begin{array}{c}\text { Control } \\
(80 \%)\end{array}$ & $\begin{array}{c}\text { Sever } \\
\text { stress }(40 \%)\end{array}$ & $\begin{array}{c}\text { Medium } \\
\text { stress } \\
(60 \%)\end{array}$ & $\begin{array}{c}\text { Control } \\
(80 \%)\end{array}$ \\
\hline A-5-6 & $35.45 c$ & $0.00 \mathrm{a}$ & $0.00 \mathrm{a}$ & $23.00 \mathrm{ab}$ & $26.15 b$ & $27.15 b$ & $5.81 \mathrm{~b}$ & $10.54 \mathrm{bc}$ & $14.44 \mathrm{bc}$ & $137 \mathrm{ab}$ & $140 \mathrm{c}$ & $141 \mathrm{c}$ \\
\hline A-124-1 & $56.67 a$ & $7.58 \mathrm{a}$ & $3.00 \mathrm{a}$ & $19.397 d$ & $21.99 \mathrm{c}$ & $24.76 \mathrm{c}$ & $4.78 \mathrm{bc}$ & $11.60 \mathrm{c}$ & $13.18 \mathrm{c}$ & $79.71 \mathrm{~g}$ & $80.90 \mathrm{~K}$ & $97.13 \mathrm{~K}$ \\
\hline A-7-100 & $25.34 d$ & $0.00 \mathrm{a}$ & $0.00 \mathrm{a}$ & $24.923 \mathrm{a}$ & $27.98 a$ & $29.89 a$ & 7.03a & $13.59 \mathrm{a}$ & $17.1 \mathrm{a}$ & $150.17 \mathrm{a}$ & $165.96 \mathrm{a}$ & $174.54 \mathrm{a}$ \\
\hline A-100-36 & $45.03 b$ & $1.34 \mathrm{a}$ & $0.00 \mathrm{a}$ & $21.33 \mathrm{~cd}$ & $21.83 \mathrm{~d}$ & $22.43 d$ & $5.73 \mathrm{~b}$ & $11.64 \mathrm{bc}$ & $13.14 \mathrm{bc}$ & $140.19 \mathrm{ab}$ & $149.89 \mathrm{~b}$ & $153.67 \mathrm{~b}$ \\
\hline A-100-13 & $49.87 \mathrm{~b}$ & $3.78 \mathrm{a}$ & $0.00 \mathrm{a}$ & $19.933 \mathrm{~d}$ & $20.5 \mathrm{~cd}$ & $21.43 \mathrm{~cd}$ & $6.78 \mathrm{a}$ & $12.76 \mathrm{ab}$ & $16.31 \mathrm{ab}$ & $124 \mathrm{c}$ & $127.65 d$ & $135 d$ \\
\hline A-100-4 & $47.78 \mathrm{~b}$ & $3.87 \mathrm{a}$ & $0.00 \mathrm{a}$ & $21.13 \mathrm{~cd}$ & $22.04 \mathrm{c}$ & $24.17 \mathrm{c}$ & $4.98 \mathrm{bc}$ & $10.54 \mathrm{bc}$ & $14.60 \mathrm{bc}$ & 99.33ef & $108.47 f$ & $112.43 \mathrm{f}$ \\
\hline A-100-3 & $46.98 b$ & $2.57 \mathrm{a}$ & $0.00 \mathrm{a}$ & $21.54 \mathrm{bc}$ & $20.39 d$ & $22.49 \mathrm{~d}$ & $3.79 \mathrm{c}$ & $8.51 \mathrm{~d}$ & $11.50 \mathrm{~d}$ & $106 \mathrm{e}$ & $110.65 \mathrm{ef}$ & $119 \mathrm{ef}$ \\
\hline A-100-17 & $38.67 \mathrm{bc}$ & $0.00 \mathrm{a}$ & $0.00 \mathrm{a}$ & $23.01 \mathrm{ab}$ & $23.89 \mathrm{c}$ & $24.29 \mathrm{c}$ & $4.00 \mathrm{c}$ & $13.44 \mathrm{bc}$ & $14.14 \mathrm{bc}$ & $113 d$ & $115.56 \mathrm{e}$ & $126 \mathrm{e}$ \\
\hline A-100-8 & $41.34 \mathrm{~b}$ & $0.00 \mathrm{a}$ & $0.00 \mathrm{a}$ & $21.98 \mathrm{bc}$ & $21.99 \mathrm{~d}$ & $22.57 \mathrm{~d}$ & $6.87 \mathrm{a}$ & $11.97 \mathrm{ab}$ & $15.98 \mathrm{ab}$ & $108.34 \mathrm{e}$ & $111.85 \mathrm{ef}$ & $119.56 \mathrm{ef}$ \\
\hline AH1-99 & $65.45 a$ & $9.01 \mathrm{a}$ & $5.00 \mathrm{a}$ & $19.34 \mathrm{~d}$ & $20.67 \mathrm{~cd}$ & $21.24 \mathrm{~cd}$ & $5.98 \mathrm{~b}$ & $12.97 \mathrm{ab}$ & $\begin{array}{c}15 . \\
67 a b\end{array}$ & $78.34 \mathrm{~g}$ & $89.56 \mathrm{~g}$ & $94 \mathrm{~g}$ \\
\hline
\end{tabular}

Different lowercase letters in each column indicate significant difference among treatments at $\mathrm{P} \leq 0.05$

\section{Chlorophylls and Carotenoids}

Different genotypes of almonds showed significant differences in the concentration of chlorophyll a in their leaves. maximum chlorophyll a concentration in leaf $\neg$ A-7-100and subsequently A-5-6were observed. The other genotypes had lower levels of chlorophyll a in their leaves (Table 2). Drought treatment reduced the concentration of chlorophyll a in the leaves of the studied almond genotypes; So that the highest amount of chlorophyll a was related to the control and the lowest amount was related to the treatments of -1.1 and $-1.6 \mathrm{MPa}$. (Table 2). Leaf chlorophyll b concentration was significantly affected by genotype and drought stress treatments (Table 2). The maximum concentration of chlorophyll b was observed in the leaves of A-7-100 and A-5-6 was in the second degree. Drought stress had a negative effect on chlorophyll b concentration of almond genotypes and its concentration decreased with increasing stress level. The lowest chlorophyll b concentrations were related to -1.1 and -1.6 MPa treatments and their differences with the control were significant (Table 2). Although chlorophyll b concentration decreased due to drought stress, but in no significant difference was observed between control. The results showed that under drought stress the leaf chlorophyll concentration of almond genotypes decreased. Numerous reasons have been proposed for the reduction of chlorophyll content under water stress conditions. According to Schlemmer (2005), dehydration of leaf tissues not only prevents the formation of chlorophyll, but also seems to cause chlorophyll degradation. According to reports, drought causes chloroplasts to break down and the chlorophyll concentration to decrease. Since chlorophyll and proline are both synthesized from a common precursor called glutamate, it can be argued that increasing proline synthesis under drought stress leads to a decrease in chlorophyll synthesis (Paleg and Aspinall 1981). Also chlorophyll is one of the main constituents of chloroplasts that is involved in the process of photosynthesis. The relative chlorophyll content of plant leaves is related to its photosynthesis rate, and maintaining a high chlorophyll content (ie, the green trait of the leaves) may maintain yield under drought stress (Yang et al. 2006). Studies have shown that in conditions of water scarcity, green leaves of the plant leaves lead to higher water use efficiency and higher yield of agricultural products (Egea et al. 2010). The results of the present study show that different genotypes of almond are significantly different from each other in this regard and may show different degrees of resistance to drought stress.

Table 2: Comparison of mean the leaf chlorophylls and Carotenoids concentration of selected almond genotypes in response to drought stress 


\begin{tabular}{|c|c|c|c|c|c|c|c|c|c|}
\hline \multirow[t]{2}{*}{ Genotype } & \multicolumn{3}{|c|}{ Carotenoids (mg.g fresh leaf weight) } & \multicolumn{3}{|c|}{ Pigment amount b (mg.g fresh leaf weight) } & \multicolumn{3}{|c|}{ Pigment amount b (mg.g fresh leaf weight) } \\
\hline & $\begin{array}{c}\text { Sever } \\
\text { stress }(40 \%)\end{array}$ & $\begin{array}{c}\text { Medium } \\
\text { stress(60\%) }\end{array}$ & Control(80\%) & $\begin{array}{c}\text { Sever } \\
\text { stress }(40 \%)\end{array}$ & $\begin{array}{c}\text { Medium } \\
\text { stress }(60 \%)\end{array}$ & Control(80\%) & $\begin{array}{c}\text { Sever } \\
\text { stress }(40 \%)\end{array}$ & $\begin{array}{c}\text { Medium } \\
\text { stress(60\%) }\end{array}$ & Control( $80 \%)$ \\
\hline A-5-6 & $38.0 \mathrm{a}$ & $12.1 \mathrm{a}$ & $74.1 \mathrm{ab}$ & $59.0 \mathrm{ab}$ & $12.1 \mathrm{a}$ & $74.1 \mathrm{ab}$ & $41.1 \mathrm{~b}$ & $12.2 \mathrm{a}$ & $79.2 b$ \\
\hline A-124-1 & $23.0 \mathrm{~d}$ & $88.0 \mathrm{~d}$ & $81.1 \mathrm{a}$ & $31.0 \mathrm{~d}$ & $88.0 \mathrm{~d}$ & $81.1 \mathrm{a}$ & $09.1 \mathrm{~d}$ & $40.1 \mathrm{~d}$ & $77.2 \mathrm{~b}$ \\
\hline A-7-100 & $39.0 \mathrm{a}$ & $18.1 \mathrm{a}$ & $79.1 \mathrm{ab}$ & $63.0 \mathrm{a}$ & $18.1 \mathrm{a}$ & $79.1 \mathrm{ab}$ & $57.1 \mathrm{a}$ & $18.2 \mathrm{a}$ & $76.2 \mathrm{~b}$ \\
\hline A-100-36 & $28.0 \mathrm{~b}$ & $91.0 \mathrm{~b}$ & $74.1 \mathrm{ab}$ & $44.0 \mathrm{c}$ & $91.0 \mathrm{~b}$ & $74.1 \mathrm{ab}$ & $17.1 \mathrm{c}$ & $90.1 \mathrm{ab}$ & $86.2 \mathrm{ab}$ \\
\hline A-100-13 & $29.0 \mathrm{~b}$ & $88.0 \mathrm{~b}$ & $78.1 \mathrm{ab}$ & $45.0 \mathrm{c}$ & $88.0 \mathrm{~b}$ & $78.1 \mathrm{ab}$ & $15.1 \mathrm{c}$ & $83.1 \mathrm{~b}$ & $83.2 \mathrm{ab}$ \\
\hline A-100-4 & $26.0 \mathrm{~b}$ & $90.0 \mathrm{~b}$ & $77.1 \mathrm{ab}$ & $43.0 \mathrm{c}$ & $90.0 \mathrm{~b}$ & $77.1 \mathrm{ab}$ & $13.1 \mathrm{c}$ & $98.1 \mathrm{ab}$ & $95.29 \mathrm{a}$ \\
\hline A-100-3 & $27.0 \mathrm{~b}$ & $89.0 \mathrm{~b}$ & $75.1 \mathrm{ab}$ & $41.0 \mathrm{c}$ & $89.0 \mathrm{~b}$ & $75.1 \mathrm{ab}$ & $11.1 \mathrm{c}$ & $56.1 \mathrm{c}$ & $96.34 \mathrm{a}$ \\
\hline A-100-17 & $37.0 \mathrm{a}$ & $11.1 \mathrm{a}$ & $74.1 \mathrm{ab}$ & $54.0 \mathrm{~b}$ & $11.1 \mathrm{a}$ & $74.1 \mathrm{ab}$ & $39.1 \mathrm{ab}$ & $00.2 \mathrm{ab}$ & 95.90 \\
\hline A-100-8 & $36.0 \mathrm{a}$ & $14.1 \mathrm{a}$ & $85.1 \mathrm{a}$ & $55.0 \mathrm{~b}$ & $14.1 \mathrm{a}$ & $85.1 \mathrm{a}$ & $37.1 \mathrm{ab}$ & $10.2 \mathrm{a}$ & $95.00 \mathrm{a}$ \\
\hline ) AH1-99 & $20.0 \mathrm{~d}$ & $78.0 \mathrm{~d}$ & $77.1 \mathrm{ab}$ & $29.0 \mathrm{~d}$ & $78.0 \mathrm{~d}$ & $77.1 \mathrm{ab}$ & $03.1 \mathrm{~d}$ & $33.1 \mathrm{~d}$ & $89.2 \mathrm{ab}$ \\
\hline
\end{tabular}

Different lowercase letters in each column indicate significant difference among treatments at $\mathrm{P} \leq 0.05$

Different genotypes of almonds showed significant differences in terms of total carotenoid concentration, but the effect of drought stress treatment and the interaction effects of genotype and drought stress on leaf carotenoid concentration were significant (Table 3).18). AH1-99 with a very large difference had a lower total carotenoid content than other genotypes and its difference with other genotypes was significant in this regard. Also, although drought stress changed the total carotenoid concentration and the trend of changes in total carotenoids under the influence of stress was interesting, but no statistically significant difference was observed between control treatment (Table 3). Carotenoids are the second most important group of plant pigments that in addition to their role in photosynthesis (absorption of light), also act as chlorophyll protectors (Sircelj et al. 2007). Carotenoids are defense compounds with antioxidant roles that neutralize the harmful effects of reactive oxygen species under stress. For this reason, carotenoids can be good markers for assessing drought stress (Sircelj et al. 2007).

Table 3: Comparison of mean the leaf chlorophylls and Carotenoids concentration of selected almond genotypes in response to drought stress

\begin{tabular}{|c|c|c|c|c|c|c|c|c|c|c|c|}
\hline \multirow{2}{*}{$\begin{array}{l}\frac{{ }_{v} / F_{m}}{\text { Sever }} \\
\text { tress }(40 \%)\end{array}$} & \multirow[b]{2}{*}{ Control(80\%) } & \multicolumn{3}{|c|}{ RWC(\%) } & \multicolumn{4}{|c|}{ Chlorophyll content base onSPAD } & \multicolumn{3}{|c|}{ Proline $(\mu \mathrm{g} / \mathrm{gfw})$} \\
\hline & & $\begin{array}{c}\text { Medium } \\
\text { stress(60\%) }\end{array}$ & $\begin{array}{c}\text { Sever } \\
\text { stress }(40 \%)\end{array}$ & Control(80\%) & $\begin{array}{c}\text { Medium } \\
\text { stress }(60 \%)\end{array}$ & $\begin{array}{c}\text { Sever } \\
\text { stress }(40 \%)\end{array}$ & Control(80\%) & $\begin{array}{c}\text { Medium } \\
\text { stress(60\%) }\end{array}$ & $\begin{array}{c}\text { Sever } \\
\text { stress }(40 \%)\end{array}$ & $\begin{array}{c}\text { Medium } \\
\text { stress(60\%) }\end{array}$ & Control $(80 \%)$ \\
\hline $0.613 c$ & $0.733 \mathrm{ab}$ & 0.657 & $51.412 \mathrm{c}$ & $75.5 \mathrm{ab}$ & $51.65 c$ & $34.13 c$ & $52.50 \mathrm{a}$ & $45.76 b$ & $57.66 \mathrm{c}$ & $26.34 \mathrm{c}$ & 20. 39a \\
\hline $0.751 \mathrm{a}$ & $0.791 \mathrm{a}$ & $0.761 \mathrm{a}$ & $79.27 \mathrm{a}$ & $83.1 \mathrm{a}$ & $79.27 \mathrm{a}$ & $48.791 \mathrm{a}$ & $56.11 \mathrm{a}$ & $54.87 \mathrm{a}$ & $88.41 \mathrm{a}$ & $40.63 a$ & $21.49 \mathrm{a}$ \\
\hline $0.689 \mathrm{~b}$ & $0.739 a b$ & 0.708 & $74.27 \mathrm{ab}$ & $84.18 \mathrm{a}$ & $77.11 \mathrm{ab}$ & $39.47 \mathrm{ab}$ & $53.78 \mathrm{a}$ & $46.17 \mathrm{ab}$ & $68.47 \mathrm{~b}$ & $30.4 \mathrm{bc} 7$ & $22.45 \mathrm{a}$ \\
\hline $0.659 b$ & $0.755 \mathrm{ab}$ & 0.711 & $66.024 b$ & $76.82 \mathrm{ab}$ & $70.73 \mathrm{ab}$ & $43.93 \mathrm{ab}$ & $55.33 a$ & $49.78 \mathrm{ab}$ & $67.69 \mathrm{~b}$ & $34.88 \mathrm{bc}$ & 21.89 \\
\hline $0.678 \mathrm{~b}$ & $0.747 \mathrm{ab}$ & 0.719 & $69.03 \mathrm{ab}$ & 77.93ab & $65.74 b$ & $44.03 \mathrm{ab}$ & $56.03 a$ & $51.54 \mathrm{ab}$ & $69.02 b$ & $31.53 \mathrm{bc}$ & $22.55 a$ \\
\hline $0.678 b$ & $0.749 \mathrm{ab}$ & 0.723 & $69.95 b$ & 75.95ab & $69.98 b$ & $46.36 \mathrm{a}$ & $53.36 \mathrm{a}$ & $50.39 \mathrm{ab}$ & $68.38 \mathrm{~b}$ & 47. $22 \mathrm{ab}$ & $21.96 \mathrm{a}$ \\
\hline $0.717 \mathrm{a}$ & $0.739 a b$ & 0.729 & $73.04 \mathrm{ab}$ & $81.14 \mathrm{a}$ & 77.31a & $42.8 \mathrm{ab}$ & $52.7 \mathrm{a}$ & $47.9 \mathrm{ab}$ & $82.76 \mathrm{ab}$ & $38.67 a$ & $22.16 \mathrm{a}$ \\
\hline $0.585 \mathrm{c}$ & $0.735 a b$ & 0.647 & $49.60 \mathrm{c}$ & $79.64 \mathrm{ab}$ & $56.104 \mathrm{C}$ & $32.7 \mathrm{C}$ & $50.6 \mathrm{a}$ & $44.58 b$ & $55.95 c$ & $27.17 \mathrm{C}$ & $21.66 \mathrm{a}$ \\
\hline
\end{tabular}

Different lowercase letters in each column indicate significant difference among treatments at $\mathrm{P} \leq 0.05$

\section{$\mathrm{F}_{\mathrm{v}} / \mathrm{F}_{\mathrm{m}}$, Chlorophyll content, RWC (\%) and Proline}

Different genotypes of almonds showed significant differences in the concentration of Proline in their leaves. maximum Proline concentration in leaf $\neg$ D-7(A-7-100(88.45 $\mu \mathrm{g} / \mathrm{gfw})$ and minimum) D-99(AH1-99 (55.60 $\mu \mathrm{g} / \mathrm{gfw})$ were observed. The other genotypes were located their between as levels of chlorophyll a in their leaves (Table 3-21).

The results showed in all measurements, the amount of proline was in stress treatments several times more than treatments with normal irrigation, and the highest accumulation of proline occurred in severe stress. In general, more proline was produced with increasing stress intensity. Although the genotypes that produced more proline showed moderate to high resistance, but its value in drought tolerant cultivars was not necessarily higher than other cultivars of the same species under the same stress conditions.Accumulation of amino acid proline in plant tissues in response to various non-biological stresses plays an important role against oxidative damage caused by ROS. As a result, proline plays several roles in stress adaptation. Some cultivars produce more proline in the face of drought stress, and some produce less proline, and reports from previous work suggest that drought stress leads to proline accumulation and stimulates its synthesis under drought stress in most almond cultivars or genotypes (Zamani et al. 2002; Arzani et al. 2010). This was also confirmed in the present experiment.

Examination of chlorophyll content according to SPAD criteria is a non-destructive and fast method for determining the chlorophyll content of plants. The results showed that genotype A-7-100 had the highest chlorophyll content (49.95) according to SPAD criteria among other genotypes. However, AH1-99 genotype with chlorophyll content (31.87) had the lowest value (Figure 1), which shows the greater sensitivity of AH1-99 genotype to dehydration and drought stress 
conditions. Similar results have been presented by Samandari and Elhami (2012). According to the results, there is a significant difference in chlorophyll index of different almond cultivars in response to drought stress, which will have a negative effect on yield and production (Schlemmer et al. 2005).According to the results of comparing the mean between selected almond genotypes studied in this study, it was found that genotypes A-7-100, A-100-36, A-100-8 and A-100-17 with 79.27, 74.27, 73.19 and 73.04 had the highest relative water content of leaves among other genotypes, which indicates the relative tolerance of these genotypes to drought stress. A similar report was presented by Faraloni et al. (2011) regarding the comparison of the relative water content of leaves between different species at the highest level of drought stress. According to this report, P. eburnea had the highest relative water content of leaves under severe drought stress, which shows that it was more resistant to drought stress than others. These results indicate that susceptible genotypes are less able to absorb or retain water in their leaves under drought stress and dehydration. Based on studies on different plants, the relative content of leaf water can be used as an indicator to assess the tolerance of the plant to severe stress and wilting and can be used in breeding screening (Krause et al. 1993; Gradziel; et al. 2001). Increasing the intensity of moisture stress and consequently reducing the plant's ability to absorb water reduces cell turbulence and disrupts cell division, which leads to reduced plant growth and development (Maclagan, 1993). The results of comparing the mean of the data show that drought stress has a significant effect on the ratio of variable fluorescence to maximum fluorescence (FV/Fm) of selected almond genotypes (Table 3). According to the results, AH1-99 genotype with 49.60 shows the lowest value and A-7-100 genotype with 751 has the highest value. These results indicate that genotype A-7-100 has more resistance and adaptation to drought stress than other genotypes. Yuan et al. (2005) reported that drought stress is one of the most important environmental factors to limit photosynthesis in plants, so that with the closure of the stomates, the concentration of intracellular carbon dioxide decreased and then with the accumulation of electron carriers with high energy level and the formation of free radicals disturbs the light-absorbing complexes and destroys the photosynthetic system, which leads to a decrease in photosynthetic efficiency. Other reasons for this can be found in the report of Piper et al. (2007) on drought stress, which stated that various stresses, including drought, by increasing the consumption of electron transfer chain products (NADPH and ATP), increase ferredoxin reduction and free radicals. As a result, the thylakoid membrane proteins are degraded, resulting in impaired electron transfer from the photosystem II acceptor site and reduced maximum photosystem II function, which in turn increases chlorophyll fluorescence.

\section{Activity of antioxidant enzymes}

The activity of leaf antioxidant enzymes including superoxide dismutase (SOD), peroxidase (POD), catalase (CAT) and ascorbate peroxidase (APX) were measured at the end of the stress period. The results are given in Table 3-24 shows the trend of changes in the activity of these enzymes under the influence of drought stress.

Superoxide dismutase (SOD)

Both genotype and drought stress factors had a significant effect on SOD enzyme activity in almond leaves. Almond genotypes were significantly different in this regard. The highest activity of SOD enzyme was related to genotypes A-7-100 (2.34 $\left.\mathrm{mmol} / \mathrm{gfw} \mathrm{min}^{-1}\right)$ and genotype of AH1-99 $\left(1.47 \mu \mathrm{mol} / \mathrm{gfw} \mathrm{min}^{-1}\right)$ Showed the lowest level of activity (Table 4$)$. When plants are exposed to environmental stresses, including drought stress, the activity of antioxidant enzymes in the photosynthetic apparatus protects the plant against oxidative damage (Cavalcanti et al. 2004). Superoxide dismutase (SOD) removes the superoxide anion (O2-) produced by the electron transfer chain in chloroplasts and mitochondria, and then, the $\mathrm{H}_{2} \mathrm{O}_{2}$ produced by SOD activity is eliminated by APX and POD in different parts of the cell. Enslaved. In addition, CAT also eliminates the $\mathrm{H}_{2} \mathrm{O}_{2}$ produced in the light-breathing pathway inside the proxysomes (Wang et al. 2009). The sweeping capacity of reactive oxygen species (ROS) and the reduction of their harmful effects may be associated with drought tolerance of plants (Tsugane et al. 1999).

\section{Peroxidase (POD)}

Genotype and drought stress treatments had a significant effect on POD enzyme activity in almond leaves, Almond genotypes studied in this study were significantly different in terms of POD activity and the highest activity of this enzyme was observed in A-7-100 (1.99 $\mu \mathrm{mol} / \mathrm{gfw} \mathrm{min}^{-1}$ ) and genotype of AH1-99 (1.88 $\left.\mu \mathrm{mol}^{\mathrm{gfw}} \mathrm{min}{ }^{-1}\right)$. Other genotypes were located the them between (Table 3-29). Comparison of different drought stress treatments with each other and control showed that drought stress, especially -1.1 and -1.6 MPa treatments increased POD activity compared to the control. The activity of this enzyme increased with increasing stress intensity increased

Catalase (CAT)

Both genotype and drought stress factors had a significant effect on the activity of CAT enzyme in leaves (Table 3-24). The almond genotypes studied in this study showed a significant difference in terms of CAT activity and the highest activity of this enzyme in in A-7-100 (1.64 $\left.\mathrm{mmol} / \mathrm{gfw} \mathrm{min}^{-1}\right)$ and genotype of AH1-99 (0.95 $\left.\mu \mathrm{mol} / \mathrm{gfw} \mathrm{min}^{-1}\right)$. Observed in mg / leaf) under severe drought stress conditions. Comparison of different drought stress treatments with each other and the control showed that drought stress increased CAT activity compared to the control (Table 3-29).

\section{Ascorbate peroxidase(APX)}

Genotype had significant effect on leaf APX activity and differences between different Genotypes of almonds were notable in this regard. On the other hand, APX activity was significantly affected by drought stress treatments and increased with increasing stress level (Table 3-29).

When plants are exposed to environmental stresses, including drought stress, the activity of antioxidant enzymes in the photosynthetic apparatus protects the plant against oxidative damage (Cavalcanti et al., 2004). Superoxide dismutase (SOD) removes the superoxide anion ( $\mathrm{O}^{-}$) produced by the electron transfer chain in chloroplasts and mitochondria, and then, the $\mathrm{H}_{2} \mathrm{O}_{2}$ produced by SOD activity is eliminated by APX and POD in different parts of the cell. Enslaved. In addition, CAT also eliminates the $\mathrm{H}_{2} \mathrm{O}_{2}$ produced in the light-breathing pathway inside the proxysomes (Wang et al. 2009). The sweeping 
capacity of reactive oxygen species (ROS) and the reduction of their harmful effects may be associated with drought tolerance of plants (Tsugane et al. 1999).

In scientific sources, the close relationship between high activity of antioxidant enzymes and increased resistance to drought stress has been repeatedly pointed out and emphasized. For example, in a drought tolerant clone of coffee under drought stress, the activity of SOD, CAT, and APX increased significantly compared to a drought-sensitive clone, leading to lower lipid peroxidation levels and electrolyte leakage (Lima et al. 2002). Also, a drought-resistant bean species showed higher SOD, CAT, POD and APX activity as well as lower levels of lipid peroxidation compared to its drought-sensitive species (Turkan et al. 2005). Khana-Chopra and Singh (2015) associated less damage to the membranes of a drought-resistant plant cultivar under severe drought stress conditions with higher POD and APX activity compared to a drought-sensitive cultivar. In other reports, high activity of antioxidant enzymes in cultivars of white berry (Reddy et al., 2004), olive (Ben Ahmad et al. 2009), kiwi (Wang et al. 2011) and some intermediate breeds The genus Prunus (Sofo et al. 2005) has improved drought resistance or tolerance.

In the present study, genotype and drought stress had a significant effect on the activity of leaf antioxidant enzymes including SOD, POD, CAT, APX and GR. In all genotypes, the activity of these enzymes increased under the influence of drought stress treatment. Differences between control and treated plants in terms of SOD activity in all genotypes were significant.

\section{Conclusion}

Examination of morphological and physiological characteristics of some selected almond genotypes showed a significant effect of drought stress on seedling height, stem diameter at the top of the graft, longitudinal growth of new branches and the amount of yellowing and leaf fall. Also, under drought stress, physiological characteristics such as chlorophyll index based on SPAD criteria, relative water content of leaves, and the ratio of variable fluorescence to fluorescence were maximally reduced, which showed a significant difference in some genotypes. According to the data obtained from this study, cultivar AH1-99 was identified as the most sensitive genotype and A-7-100 as the most resistant genotype to drought stress. It should be noted that the selected genotypes in this study are the result of breeding programs and no research has been done on them. With further study and research work, some of these genotypes can be identified as drought tolerant genotypes. Introduced and used in breeding and agricultural programs. the results of comparing the mean of the data show that drought stress has a significant effect on the ratio of variable fluorescence to maximum fluorescence $\left(F_{V} / F_{m}\right)$ of selected almond genotypes (Table 3). According to the results, AH1-99 genotype with 49.60 shows the lowest value and A-7-100 genotype with 751 has the highest value. These results indicate that genotype A-7-100 has more resistance and adaptation to drought stress than other genotypes. Yuan et al. (2005) reported that drought stress is one of the most important environmental factors to limit photosynthesis in plants, so that with the closure of the pores, the concentration of intracellular carbon dioxide decreased and then with the accumulation of electron carriers with energy level High and the formation of free radicals disturbs the lightabsorbing complexes and destroys the photosynthetic system, which leads to a decrease in photosynthetic efficiency. Other reasons for this can be found in the report of Piper et al. (2007) on drought stress, which stated that various stresses, including drought, by increasing the consumption of electron transfer chain products (NADPH and ATP), increase reductant reductase and radicals. The thylakoid membrane proteins are released and degraded, resulting in impaired electron transfer from the photosystem II acceptor site and reduced maximum photosystem II function, which in turn increases chlorophyll fluorescence

\section{Abbreviations}

\section{Fv/Fm}

Fluorescence variable / Fluorescence maximum

GN15

(Garfi almond x Nemared peach hybrids) (Zaragosa, Spanish origin)

WL

Fresh weight of Leaf

FWL

Dry weight of Leaf

SWL

Saturated weight of Leaf

ROS

Reactive oxygen species (

SOD

Superoxide dismutase

CAT

Catalase

APX

ascorbate peroxidase

POD 
peroxidase

SPAD

Chlorophyll index was evaluated based on SPAD criterion

RWC

Relative leaf water content

$\mathrm{Ch}_{\mathrm{a}}$

Chlorophyll A

$\mathrm{Ch}_{\mathrm{b}}$

Chlorophyll B

$\mathrm{C}_{\mathrm{x}+\mathrm{c}}$

Total carotenoids

\section{Declarations}

\section{Acknowledgments}

The authors acknowledge for Iran National Science Foundation (INF) the financial support. We would also like to thank all donors who supported this work particularly almond breeding and physiology teams at TFRC, Iran for their contribution.

\section{Availability of data and materials}

Not applicable.

\section{Ethics approval and consent to participate}

Not applicable.

\section{Consent for publication}

Not applicable.

\section{Competing interests}

The authors declare that they have no competing interests.

\section{Authors' contributions}

Ali Imani, AliReza Talaei, Vahid Abdossi and Mohamad Reza Asghari designed the study; Shabnam Gohari performed experiments; Shabnam Gohari and Ali Imani wrote the manuscript. All authors read and approved the final manuscript.

\section{References}

Aker NR, Rosenqvist E (2004) Applications of chlorophyll fluorescence can improve crop production strategies: an examination of future possibilities. J Exp Bot 55 (403):1607-1621

Anjum SA, Xie X, Wang LC, Saleem MF, Man C, Lei W (2011b) Morphological, physiological and biochemical responses of plants to drought stress. Afric J Agric Res 6 (9):2026-2032

Ashraf M, Foolad MR (2007) Roles of glycine betaine and proline in improving plant abiotic stress resistance. Environ Exp Bot 59: $206-216$

Aspinall D, Paleg LG (1981) Proline Accumulation: Physiological Aspects, In: Paleg, L.G. and Aspinall D, Eds, The Physiology and Biochemistry of Drought Resistance in Plants, Academic Press, Sydney, 205-241

Arzani K, Yadollahi A, Ebadi A, Wirthensohn M (2010) The relationship between bitterness and drought resistance of almond (Prunus dulcis Mill.). Afric J Agric Res 5(9):861-866.

Baker NR, Rosenqvist E (2004) Applications of chlorophyll fluorescence can improve crop production strategies: an examination of future possibilities. J Exp Bot 55 (403): 1607-1621

Bates LS, Waldren RP, Teare ID (1973) Rapid determination of free proline for waterstress. Plant Soil 39:205-207. doi: 10.1007/BF00018060. 
Berman ME, Dejong TM (1996) Water stress and crop load effects on fruit fresh and dry weights in peach (Prunus persica). Tree Physiol 16: 859864

Cavalcanti FR, Oliveira JTA, Martins-Miranda AS, Viegas RA, Silveira JAG (2004) Superoxide dismutase, catalase and peroxidase activities do not confer protection against oxidative damage in salt-stressed cowpea leaves. New Phytol 163:563-571

Chakhchar A, Lamaoui M, Wahbi S, Ferradous A, El Mousadik A, Ibnsouda- Koraichi S, Filali-Maltouf A, CE Modafar (2015) Leaf water status, osmoregulation and secondary metabolism as a model for depicting drought tolerance in Argania spinosa. Acta Physiol Planta 37(4):80-96 doi: 10.1007/s11738-015-1833-8.

Egea G, Pedro A, Nortes A, Marı́a M, Gonza' lez-Real A, Baille A (2010) Agronomic response and water productivity of almond trees under contrasted deficit irrigation regimes Rafael Domingo b,cAgricultural Water Management 97: 171-181

Faraloni C, Cutino I, Petruccelli R, Leva, AR Lazzeri S, Torzillo G (2011) Chlorophyll Fluorescence Technique as a rapid tool for in vitro screening of olive cultivars (Olea europaea L.) Tolerant to Drought Stress. Environ Exp Bot 73:49-56

Ge Y, He X, Wang J, Jiang B, Ye R, Lin X (2014) Physiological and biochemical responses of Phoebe bournei seedlings to water stress and recovery. Acta Physiol Plant 36:1241-1250. doi: 10.1007/s11738-014-1502-3

Germanà C, (1997) Experience on the response of almond plants (Amygdalus communis L.) to water stress. Acta Hortic 449:497-503 Gholizadeh A (2009) Evaluation of SPAD Chlorophyll Meterin in two different rice growth stage and its temporal variability. Eur j Sci Res 4:591598.

Guerfel M, Baccouri O, Boujnah D, Chaïbi W, Zarrouk M (2009) Impacts of water stress on gas exchange, water relations, chlorophyll content and leaf structure in the two main Tunisian olive (Olea europaea L.) cultivars Sci Hortic 119(3):257-263. doi: 10.1016/j. scienta.2008.08.006.

Haider MS, Kurjogi MM, Khalil-ur-Rehman M, Pervez T, Songtao J, Fiaz M, Jogaiah S, Wang C, Fang J (2018) Drought stress revealed physiological, biochemical and gene-expressional variations in 'Yoshihime' peach (PrunusPersica L) cultivar, J Plant Interact 13:1, 83-90, DOI: $10.1080 / 17429145.2018 .1432772$

Hernández I, Alegre L, Munné-Bosch S (2004) Drought-induced changes in flavonoids and other low molecular weight antioxidants in Cistus clusii grown under Mediterranean field conditions. Tree Physiol 24(11):1303-11

Jimenez S, Dridi, J, Gutierrez D, Moret D, Irigoyen JJ, Moreno MA, Gogorcena Y (2013) Physiological, biochemical and molecular response in four Prunus rootstocks submitted to drought stress. Tree Physiol 33: 1061-1075. https://doi.org/10.1093/treephys/tpt074 [Google Scholar]

Khanna-Chopra R, Singh K (2015) "Drought resistance in crops: physiological and genetic basis of traits for crop productivity," in Stress Responses in Plants: Mechanisms of Toxicity and Tolerance, eds BN Tripathi and M Müller (New York, NY: Springer), 267-292

Karimi S, Yadollahi A, Arzani K (2013) Responses of Almond Genotypes to Osmotic Stress Induced in Vitro. J Nuts 4(4): 1-7

Karimi S, Yadollahi A, Arzani K, Imani A (2015) Gas exchange response of almond genotypes to water stress. Photosynthetica 53(1): 29-34. doi: 10.1007/s11099-015-0070-0. Karimi, S., A. Yadollahi R, Nazari-Moghadam A, Imani A, Arzani K (2012b) In vitro screening of almond (Prunus dulcis (Mill.)) genotypes for drought tolerance. J Biol Environ Sci 6(18):263-270

Khoyerdi FF, Shamshiri MH, Estaji A (2016) Changes in some physiological and osmotic parameters of several pistachio genotypes under drought stress. Sci Hort 198:44-51

Maclagan JL (1993) Effect of drought stress on the water relation in Brassica Species. Can J Plant Physiol Sci 73: 225-229

McMichael BL, Jordan WR, Powell RD (1973) Abscission process in cotton: Induction by plant water deficit. Agron J, 65 : $202-204$

Krause SC, Raffia KF, Wagner MR (1993) Tree Response to Stress: A role in sawfly Outbreaks? pp. 211-227. In: MR Wagner and KF Raffa (eds.) Sawfly life history adaptations to woody plants. Academic Press, New York.

Munné-Bosch S, Jubany-Marí T, Alegre L (2003) Enhanced photo- and antioxidative protection, and hydrogen peroxide accumulation in droughtstressed Cistus clusiiandCistus albidusplants. Tree Physiol 23(1):1-12

Nezhadahmadi A, Hossain Prodhan Z, Faruq G (2013) Drought tolerance in wheat. Sci World J doi: 10.1155/2013/610721. 
Ohashi, Y, Nakayama N, Saneoka H, Fujita K (2006) Effects of drought stress on photosynthetic gas exchange, chlorophyll fluorescence and stem diameter of soybean plants. Biol. Plant 50(1):138-141. doi: 10.1016/j.envexpbot.2005.06.021.

Parida AK, Das AB (2005) Salt tolerance and salinity effects on plants. A rev Ecotoxicol and Environ safety 60:324-349

Piper Fl, Corcuera LJ, Alberdi M, Lusk C (2007) Differential photosynthetic and survival responses to soi drought in two evergreen Nothofagus species. Annals forest Sci 64: 447-452

Reddy AR, Chaitanya KV, Jutur PP, Sumithra K (2004) Differential antioxidative responses to water stress among five mulberries (Morus alba L.) cultivars. Environmental and Experimental Botany, 52: 33-42.

Rigling A, Briihlhart H, Barker O, forster T, Schweingruber FH (2003) Effect of Romero P, Navarro JM, Garcia F, Pablo O, Botia O (2004) Effects of regulated deficit irrigation during the pre-harvest period on gas exchange, leaf development and crop yield of mature almond trees Tree Physiol $24,303-312$.

Rouhi V, Samson R, Lemeur R,Van Damme P (2007) Photosynthetic gas exchange characteristics in three different almond species during drought stress and subsequent recovery. Environmental and Experimental Botany. 59:117-129

Ryan M. G. 2013. Tree responses to drought. Tree Physiol 31: 237-239.

Samandari Gikloo T, Elhami B (2012) Physiological and morphological responses of two almond cultivars to drought stress and cycocel. Int Res J App/Sci 3 (5):1000-1004.

Schlemmer MR, Francis DD, Shanahan JF, Schepers JS (2005) Remotely measuring chlorophyll content in corn leaves with differing nitrogen levels and relative water content. Amer Soci Agron 97 (1): 106-112

Socias I, Company R, Gradziel TM (2017) Almonds: Botany, Production and Uses. Boston, MA: CABI.

Stocker $O$ (1960) Physiological and morphological changes in plant due to water deficiency. Arid Zon15: 63-104.

Sun, C, Li X, Hu Y, Zhao P, Xu T, Sun J, Gao X (2015) Proline, sugars, and antioxidant enzymes respond to drought stress in the leaves of strawberry plants. Korean J Hortic Sci Technol 33(5): 625-632. https://doi.org/10.7235/hort.2015.15054

Sanchez FJ, Manzanares M, De Andres EF, Tenorio JL, Ayerbe L (1998) Turgor maintenance, osmotic adjustment and soluble sugar and proline accumulation in 49 pea cultivars in response to water stress. Field. Crop. Res 59:225-235. doi: 10.1016/S0378-4290(98)00125-7

Torrecillas A, Ruiz-Sanchez M C, Hernanseaz A (1989) The response of young almond trees to different drip-irrigated conditions: Development and yield. Hort. Sci, 64(1): 1-7

Tsugane K, Kobayashi K, Niwa Y, Ohba Y, Wada K, Kobayashi H (1999) A recessive Arabidopsis mutant that grows photoautotrophically under salt stress shows enhanced active oxygen detoxification. The Plant Cell 11:1195-1206

Turkan S, Bor M, Ozdemir F, Koca H (2005) Differential responses of lipid peroxidation and antioxidants in the leaves of drought-tolerant $P$. acutifolius Gray and drought-sensitive P. vulgaris L. subjected to polyethylene glycol mediated water stress. Plant Sci 168: $223-231$.

Wang WB, Kim YH, Lee HS, Kim KY, Deng XP, Kwak SS (2009). Analysis of antioxidant enzyme activity during germination of alfalfa under salt and drought stresses. Plant Physiol Biochem 47:570-577

Yang CM, Chang KW, Yin MH, Huang HM (1998) Methods for the determination of the chlorophylls and their derivatives. Taiwania 43(2): 116122.

Zokaee Khosroshahi MR, Esna-Ashari M, Ershadi A, Imani A (2014) Morphological changes in response to drought stress in cultivated and wild almond species. Int J Agric Crop Sci 1: 79-92. https://doi:10.22059/ijhst.201

Vitagliano C, Sebastiani L (2002) Physiological and biochemical remarks on environmental stress in olive (Olea europaea L.). Acta Hortic 586:435-440. doi: 10.17660/ Acta Hortic 2002.586.89.

Yuan S, Liu WL, Zhang NH, Wang MB, Liang HG, Lin HH (2005) Effects of water stress on major photosystem II gene expression and protein metabolism in barley leaves. Physiol Plantar 125: 464-473

Zamani Z, Taheri A, Vezvaei A, Poustini K (2002). Proline content and stomata resistance of almond seedlings affected by irrigation intervals. Acta Hortic 591: 411-416.

Page $11 / 12$ 
Figures



Figure 1

Soil water retention curve of the experimental soil. 